Article

\title{
Lack of Spatial Approach in Urban Density Policies: The Case of the Master Plan of Tehran
}

\author{
Mostafa Ghadami ${ }^{1, *}$, Andreas Dittmann ${ }^{1}$ and Taher Safarrad ${ }^{2}$ \\ 1 Department of Geography, Justus Liebig University Giessen, 35390 Giessen, Germany; \\ Andreas.Dittmann@geogr.uni-giessen.de \\ 2 Geography and Urban Planning Department, University of Mazandaran, Babolsar 13534-47416, Iran; \\ t.safarrad@umz.ac.ir \\ * Correspondence: Mostafa.ghadami@geogr.uni-giessen.de; Tel.: +49-1636904366
}

Received: 15 July 2020; Accepted: 1 September 2020; Published: 4 September 2020

check for updates

\begin{abstract}
This paper aims to investigate the approach of density policies in the Tehran Master Plan and the consequences of ignoring the macro spatial scale in density policymaking. In this study, the floor area ratio (FAR) regulations of the Master Plan of Tehran (which are defined by specific land use zones) are used as one of the main densification tools. Then, employing the Getis-Ord Local G and geographic weighted regression (GWR) statistical tests, Arc GIS 10.3 software, and population and employment variables, the spatial outcomes of the Master Plan density policies were modeled. In this research, both population and employment (job) variables and their relationship were utilized to depict the urban spatial structure of the city. The model will show the resulting spatial structure of Tehran if the densification policies of the plan are realized. The findings of the research are surprising, as they indicate that the Master Plan's densification policies would worsen the current spatial structure by disrupting the current population and employment spatial structure and neglecting their logical relationships. In fact, the Master Plan would change the current polycentric structure into a highly dispersed structure due to its densification approach, which is mainly based on the neighborhood micro scale.
\end{abstract}

Keywords: density; spatial approach; urban spatial structure; Tehran

\section{Introduction}

Urban spatial structure is an outcome of the long-term interaction between various actors, regulations, and practices, and it has a significant influence on the quality of urban development [1-11]. As urban physical interventions are costly and time-consuming [4], taking the long-term and structural consequences of physical policies such as density into consideration is crucial. This issue should especially be more highlighted in developing countries that are experiencing rapid urbanization and sprawl on the one hand, and suffering from financial deficits on the other [12-18].

Urban spatial structure is influenced by the density pattern of the population and activity in the urban space. Therefore, the approach of the density policies will directly affect urban spatial structure and urban sustainability [19-21]. Density is undoubtedly considered to be one of the most important physical measures in urban research. However, for decades this measure in scientific research, as well as policy-making sectors, has been a vague concept [22]. In reviewing the relevant research, there is a clear heterogeneity in the results. While many scholars emphasize the positive role of density in urban development, there are many others that refute any significant influence [21].

The importance of density in the quality of urban development has been widely investigated by many researchers. Compact and high-density cities are recognized as the most effective urban systems and are positively related to urban life [23-26]. The important issue in supporting densification is 
weighing the advantages of agglomeration against the disadvantages of sprawl. Accordingly, the main discussions about low-density urban growth refer to the disadvantages of sprawl, which are related to the higher degree of loss of agricultural lands, higher development expenses, inefficient extension of infrastructure, and increase of travel times [27].

On the other hand, there is plenty of research that shows contradictory results. Some studies note that densification is accompanied by issues such as an increase in traffic, air, and sound pollution, but it probably does not lead to a decrease in vehicle mileage traveled (VMT) and energy consumption. In addition, the ecological advantages of dense urban areas come under question when opposing experiences or behavioral patterns are observed [28].

The prevalence of high density and the compact form paradigm in developed countries has influenced the density policies of developing cities to envision plans under the aegis of a "compact city" concept [24]. However, high-density developments are paradoxical in the context of developing countries. On the one hand, the lack of financial resources in most third world cities make such policies popular, as urban management has more chances to decrease overall costs of infrastructure development and maintenance, thereby reducing the cost of per capita resource requirements and in turn increasing efficiency in service access and delivery [24,29]. On the other hand, high-density policies are criticized in the context of developing countries due to the fact that many of these cities are already highly dense. Consequently, there is doubt that densification of an already dense urban area would achieve the desired goals. Furthermore, opponents of densification in developing cities point out the main characteristics of these cities, such as crowding, already dense spaces, old and exhausted infrastructures (especially in the old wards), low living standards, congestion, and pollution [30,31].

In this regard, the important point is that density regulations in the municipalities and local government sectors are somehow informed by scientific research. The question here is: on which research results do these policies rely? Notably, the effectiveness of density regulations will be undermined by heterogeneous research results.

By reviewing the different studies that have employed density as the measure, it is revealed that ambiguity in the results stems from two main reasons. The first is the use of an unequal geographical unit as the denominator in the calculation of density. Many of the studies calculate density using available official statistics of population or employment that are based on administrative boundaries; differences in the system of administrative boundaries as the denominator can change the value of density and undermine the interpretability of the density value in different contexts. To eliminate the effect of the artificial boundaries in density modeling, we used the raster layer of Geographic Information System (GIS), which is based on the grid cell of variables such as population and employment. With this method, the modeled map of density was based on the grid cells that have the same area.

Furthermore, density-related research studies utilize different geographical scales. Many studies that focus on the urban form and workability, for example, mainly employ the neighborhood scale to analyze the impact of density on human activities [32]. Others use the gross or average density as a universal value at the municipal or regional scale [33-36].

This issue can be more critical for municipalities and local governments. The mentioned approach of density consideration that either focuses on the micro scales (such as parcels or neighborhoods) or the gross average values is widely applied in the formulation of spatial policies by local governments and municipalities. Consequently, the urban spatial structure that will be formed or affected by the density regulations in every parcel or neighborhood is missed or at least is not analyzed precisely. In other words, while there are precise geometric measures of density for every single parcel, like pieces of a larger puzzle, urban structure as the resulting big picture is often overlooked in densification policies.

The functions of density as a key physical measure in urban planning can be modified in different spatial structures. A definite average value of density at the city or neighborhood scale can be interpreted as high or low, but the same value of density can be applied in a variety of urban spatial structures [37]. In other words, the spatial pattern of high- or low-density spots of population and employment in the city or city-region structures can provide more precise measurements to assess the 
impacts of density in urban development than a gross average value of density at the neighborhood or city scale [38].

While this research is in line with the contradictory discussions related to density, it employed a different approach. The paper tries to fill a gap in the relevant research area by focusing on the urban spatial structure as an overlooked (or less considered) scale in densification policies. This research also provides an experience from a different context, that of a developing country. The experiences from the case study subject of this research, Tehran (the capital city of Iran), will exemplify how densification policy can result in irreversible and long-standing spatial consequences when it ignores the macro spatial scale.

When considering the spatial changes of Tehran during the years before and after the approval of the Master Plan (2007) — especially in terms of density—-there appears to be a clear gap between the spatial goals and policies of the plan and the status quo. To investigate the reason for this gap, the first question of this research is related to the Master Plan's approach to density policies. More than 10 years after the approval and implementation of the Master Plan of Tehran, there is now a proper basis to assess its densification policies and its results.

This paper consists of several interconnected parts. In the introduction, an overlooked scale in density research and the policy-making sector is discussed. In the second section, a theoretical background is provided to showcase the contradictory results about the impacts of density in urban development. The importance of urban spatial structure in density research is also considered in this section. In the method section, the techniques of data gathering and analysis are explained in detail. For clarification, in the next section, a brief overview of the spatial changes of Tehran is also provided. In the fifth section, Tehran's densification policies are reviewed and analyzed on the bases of the macro spatial approach. Finally, the results are summarized and synthesized in the discussion and conclusion section.

\section{Density Debate and the Matter of Scale}

Urban densification refers to the concentration process of the population, building units, employment, and transportation in a defined area. Densification could have several economic, social, and environmental consequences. Many studies emphasize being in favor of the effectiveness of densification in achieving urban sustainable development goals, while many others argue the opposite. This study refers to some of them as its theoretical background.

According to Muñiz and Galindo (2005), high-density cities have considerably lower footprints, accommodating a higher population in more limited spaces [39]. This translates to a lower consumption of valuable land resources. Furthermore, by shortening the distance between the urban functional areas, urban densification has a significant impact on decreasing the dependency on cars, the VMT, and the emission of greenhouse gases [40-43]. A denser population also requires adequately meeting the demand for public services, which justifies their development [44] and, therefore, improves their efficiency [45,46].

On the other hand, the critics' view indicates a paradox in the advantages and disadvantages of densification [23]. The proponents of sprawl believe that densification requires sacrificing some individuals' aspirations in order to achieve the social goals of sustainable development [37]. Bramley et al. (2009) and Neuman (2005), for example, believe that an urban structure is not sustainable when it limits the daily lives of people.

The ecological advantages of a dense urban area are the subject of debate [28]. Some studies also note that while densification is accompanied by several issues, such as an increase in traffic, air, and sound pollution, it probably does not lead to a decrease in VMT and energy consumption. Proponents claim that low density and sprawl development has some advantages, including ease of access to green spaces, the easing of traffic, and shorter commutes for those living in the suburbs. Furthermore, some studies indicate that perceived environmental quality in higher density cities, according to surveyed inhabitants, is lower [47,48]. 
All in all, considering density as the single criterion in achieving a sustainable urban development seems to be misleading, and the debates over its advantages and disadvantages are confusing. One of the main reasons for such contradictory results in the density-related literature is the matter of reference area or scale [22,49].

Many of the earlier studies on density take a general approach by only using aggregate data $[33,34,50,51]$. Referring to the average density as a gross and universal indicator, they smooth out the spatial pattern of population and employment clusters in the city. Indeed, average density cannot reflect the variations of density and, thus, fails to reflect the urban structure accurately [37,52]. In this way, the validity and interpretability of density indicators often suffer from a lack of-or an unclear-definition of a spatial relationship [53].

Many other studies that include density focus on the neighborhood scale $[3,54,55]$. However, while the neighborhood scale is a more accurate measure than gross city-wide density, the problem of the reference unit still remains. Unequal reference areas-especially at the neighborhood scale, which are usually based on administrative boundaries-undermine the comparability of the studies. In addition, focusing just on the neighborhood scale as a micro scale is too narrow to explain the totality of urban spatial impact [32].

In general, despite the significant influence of urban spatial structure, only a few studies have focused on urban structure in their investigation of density [4,49,56-58].

Urban spatial structure as the macro scale reflects the distribution pattern of the population, employment, and communication network, which has great influence on urban development variables $[21,22,43]$. In the case of $\mathrm{VMT}$, urban structural variables such as population weighted density (PWD), population centrality, and jobs-to-housing ratio can significantly reduce VMT and $\mathrm{CO}_{2}$ emissions from the transportation sector. At the neighborhood scale, however, the results are very narrow [32,59]. Furthermore, the results of some other studies imply that the macro scale of urban structure can overwhelm neighborhood-scale effects $[5,32,55]$.

The critical point in densification policy is to consider the urban spatial structure as the macro frame in which the micro unit densification projects are going to be implemented. The same average density of a neighborhood or city can have multiple spatial arrangements and functional profiles [60-62]. Thus, by affecting population and activity distribution patterns, the coordination of densification policies with the spatial structure of the city can enhance the effectiveness of density in increasing urban efficiency and environmental quality $[60,63,64]$.

\section{Materials and Methods}

This study consists of several interrelated steps. In the first step, the density regulations and policies were drawn out from Master Plan of Tehran. In this plan, Tehran was divided into four main functional or macro zones and defined land-use sub-zones. In every sub-zone, the regulations for land use, maximum allowed floor area ratio (FAR), maximum number of floors, and maximum building coverage area were provided (see Tables 2-4).

In the second step, the set of aforementioned regulations were entered into the GIS polygon layer of the land use sub-zones via the Arc GIS 10.3 software. Considering the regulations, the following formula was used to calculate the possible populating capacity of each sub-zone. In the case of the green macro zone and the industrial zones, a populating capacity of zero was utilized.

$$
P P S=\sum_{j} \alpha i \cdot M a x \gamma i \cdot \beta r i \cdot d p i
$$

PPS: possible populating of sub-zone.

$\alpha i$ : area of sub-zone (in hectares).

Max yi: maximum allowed FAR.

$\beta r i$ : potential residential development proportion (\%).

dpi: assumed population density (100 P/ha). 
The potential residential development proportion was determined for the mixed-use macro zone in the plan (Table 3). In this research, it was determined as $60 \%$ for residential sub-zones and $20 \%$ for commercial sub-zones.

For the calculation of the possible growth of commercial activities in the sub-zones, $\beta r i$ was replaced by the potential commercial development proportion ( $\beta c i)$ in Equation (1) and the minimum density of activity per hectare was determined to be 16 (i.e., 16 activities per hectare) (Equation (2)).

$$
P C S=\sum_{j} \alpha i \cdot M a x \gamma i \cdot \beta c i \cdot d c i
$$

PCS: possible growth of commercial activities in sub-zone.

$\alpha i$ : area of sub-zone (in hectares).

Max $\gamma$ i: maximum allowed FAR.

$\beta c i$ : potential commercial development proportion (\%).

$d c i$ : assumed commercial activity density (16 activities/ha).

The potential commercial development proportion $(\beta c i)$ refers to the proportion of suitable land area for commercial activities in every macro and sub-zone. According to the Master Plan, this proportion was determined as $20 \%$ for the residential macro zone and $60 \%$ for the commercial and mixed-use macro zones.

For the modeling of the spatial pattern of possible populating of sub-zone (PPS) and possible growth of commercial activities in sub-zone (PCS), the Getis-Ord Local G Statistic [65] was used. Compared to the global Moran's I and local Moran statistics model, this model has the advantage of distinguishing the hot density clusters (high density) and the cold density clusters (low density), while Moran's I statistics model analyzes similar clusters in terms of their quantitative or qualitative values [66]. In this research, the resolution of the raster maps was $100 \mathrm{~m} \times 100 \mathrm{~m}$.

$$
G_{i}(d)=\frac{\sum_{j} w_{i j(d) x i}}{\sum_{j} x j}
$$

where $x i$ is the population number or density value of cell $i$, wij $(d)$ is the binary neighborhood function, and $i$ can equal $j$ given the expected value and variance for each cell.

Geographic weighted regression (GWR) was employed to calculate the spatial relationship between the population and employment spatial patterns, which were modeled based on the density regulations of the Master Plan. In addition, the relationship between the spatial pattern of the population of Tehran and the resulting spatial pattern of the population (of the plan) were analyzed by GWR (Equation (4)).

$$
y i=\beta 0(u i, v i)+\sum_{j=1}^{m} \beta j[u i, v i] x i j+\varepsilon i
$$

where $y i$ is the dependent variable; $i$ represents the location of the study area; (ui,vi) denotes the location of the ith observed location; $\beta 0(u i, v i)$ indicates the regression parameter at the location of observation $i$, which is a function of the geographical position; $x i j$ is the independent variable; and $\varepsilon i$ is the random error of the ith region [67].

We considered population and employment simultaneously in the study of urban spatial structure, as there is a limited number of studies that have done so. Investigation of the spatial relationship between these two variables provides a high-resolution picture of the urban structure.

The resulting raster maps depict the possible spatial structure of Tehran according to the density policies of the Master Plan in every single sub-zone.

For the next step, the current spatial structure of Tehran and its changes during 1996-2011 were modeled by the Getis-Ord Local G Statistic. Then the current structure was compared with the resulting spatial structure of Tehran based on the density regulations. The GIS layers of the census 
blocks published by the statistical center of Iran $(1996,2006$, and 2011) were used as the basis of the geo-statistical analysis of the current spatial structure of Tehran.

In order to eliminate biases due to the administrative boundaries in spatial modeling, we relied on the grid cells (raster layer), which comprise the standardized datasets containing the value grids of population and employment. This approach removes the influence of official boundaries as the reference unit in spatial modeling. Finally, in order to provide a clear understanding, the grid cell results were classified based on the urban districts.

This research employed the new geographic division of Tehran, in which the whole city is divided into the main urban districts (center, inner, and outer wards) and the main geographical directions. It must be noted that Tehran consists of 22 administrative municipal regions (AMRs), but the boundaries of these AMRs are not compatible with the aforementioned divisions.

In order to divide Tehran into new geographical wards, this paper referred to Ghadami and Newman's research [20] (Figure 1), in which specific criteria were used for defining the boundaries of the three main areas, including the physical development pattern of Tehran from its first years of formation to the present (i.e., the historical process), highways and main streets, the main functions and land uses in Tehran, and residential complex developments on the outskirts, such as Ekbatan, Apadana, Shahrake Gharb, and Hafthouze.

[T] he center ward is surrounded by the streets of Enghelab, Karegar, Shoosh and 17 Shahrivar. The main functions of the city are located in this area, such as the Bazaar, parliament, some ministries, main courts, universities, embassies, and main commercial corridors. The inner area that developed over the decades gradually around the center consists of four wards and is limited by highways: Resalat and Hakim from the north, Saidi from the west, Qasvin and Besat from the south, Emam Ali and Sabalan from the east. The outer wards are located beyond these highways in which some of the huge residential complex projects such as Shahrake Gharb, Shahrake Ekbatan and Apadana were built before the revolution.

—Ghadami and Newman [20]

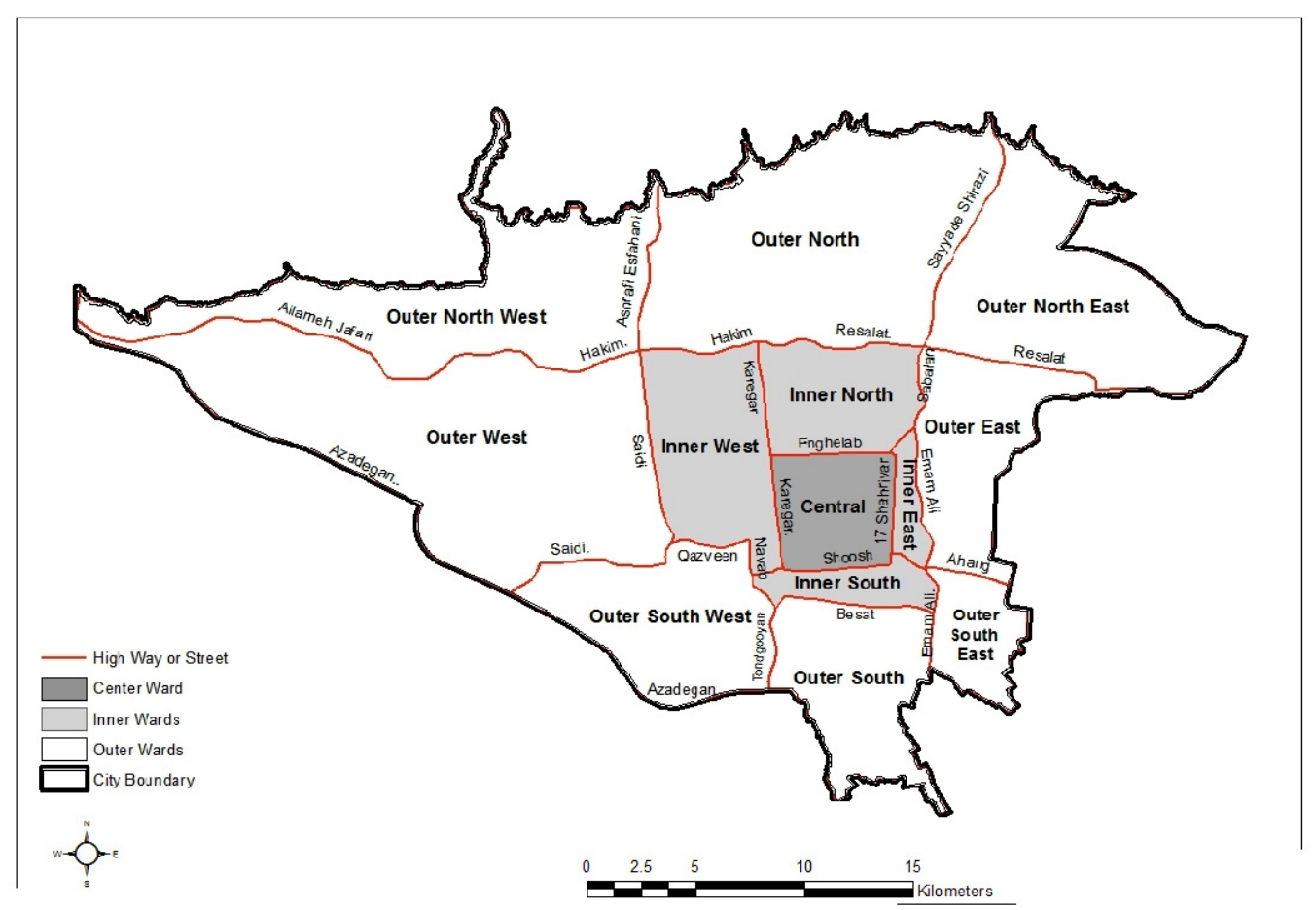

Figure 1. Main wards of Tehran [20]. 


\section{Results}

\subsection{Brief Review of Tehran's Spatial Characteristics (1996-2011)}

The city of Tehran, which had an average population density of 128 per hectare in 2011, is considered to be a dense city (Table 1). According to the interests of private investors, the military, as well as governmental and semi-governmental institutions, the outer north and west wards (as the high and upper-middle social class residential areas) have been experiencing rapid and major building construction growth $[17,68]$.

Table 1. Changes in population and density of Tehran (1996-2011) [69-71].

\begin{tabular}{cccc}
\hline Year & Population (Number) & Census Area (km) & Population Density (P/ha) \\
\hline 1996 & $6,758,845$ & 707.5 & 95 \\
2011 & $8,154,051$ & 636 & 128 \\
\hline
\end{tabular}

The central area of Tehran comprised three percent of the city's population (0.209 million) in 2011, while $83 \%$ (6.7 million) lived in the outer areas (Figure 2). Of the total population living in the outer areas, the north and south wards housed over 58\% (3.97 million) and 20\% (1.39 million), respectively [20].

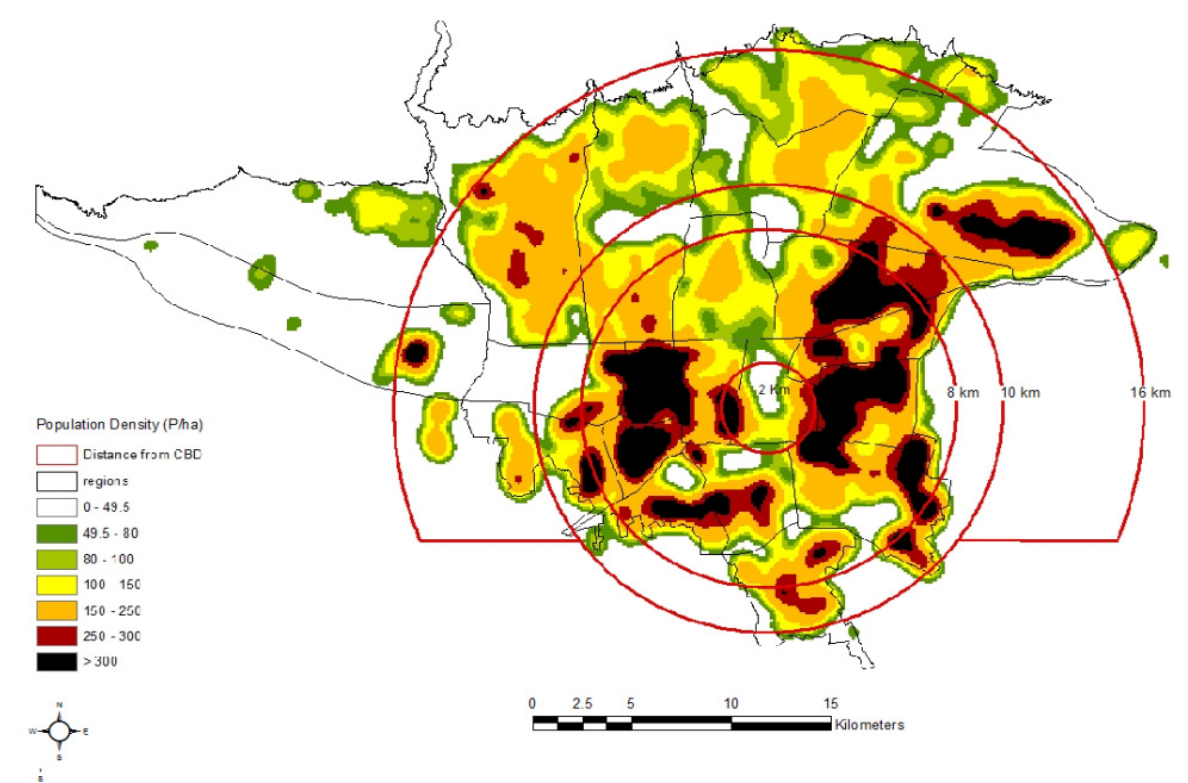

Figure 2. The spatial pattern of the population of Tehran 2011 [20].

With the wider areas of the central, inner, and south wards of Tehran having vulnerable and worn urban fabrics [16,17,68-79], the urban management failed in introducing positive spatial changes with the goal of settling more people and increasing employment in these areas. In fact, the population proportion of the central area has been reduced by $40 \%$ between 1996 and 2011. This trend has also been observed in the inner area, with a reduction of $28 \%$ [20].

Based on the employment variable, the spatial structure of Tehran in 2006 indicates a polycentric structure with a higher employment concentration in the central and inner areas (Table 6).

\subsection{The Density Policies of the Tehran Master Plan and Its Spatial Outcomes}

Urban densification (especially FAR regulations) has been a long-standing controversial issue between academia and municipalities in Iran [74]. Despite the expected effectiveness of the densification strategy to achieve sustainable urban forms in the context of developing countries, the nature of the 
approach to this strategy in Iran is mainly driven by monetary and non-spatial concerns. For instance, Tehran Municipality (as the capital city) is highly dependent on the revenues obtained from the building construction tax, fines, and the sales of extra floor area ratio (FAR) [17,74-77]. Before the Master Plan of Tehran (2007), the density policies were determined based on the simple individual regulations focusing just on the parcel area and the adjacent road width. The Master Plan was approved in response to the problems related to the urban development policies and the unplanned densification process.

The High Council of Urban Planning and Architecture of Iran approved the new Master Plan in December 2007 [77]. The plan was designed based on a projection of 9.1 million expectant inhabitants in the next 10 years. Moreover, the plan took into consideration $20 \%$ additional population (up to 10.5 million) to encourage more building construction and avoid a downturn in the housing market [78]. Some of spatial goals of the Master Plan are listed below:

- Stabilization of residential land uses; development of public spaces and services.

- Economic prosperity by strengthening the current commercial and service zones, and ensuring efficient uses of such spaces for creating new job opportunities.

- Preservation of the environment (especially considering water, air, noise, and natural resources) and immunization of the city against natural hazards.

- Development of the public transportation infrastructure and road networks, as well as travel demand management.

- Improving the quality of the urban environment and its physical fabric via land-use zoning and defining rehabilitation, renewal, and reconstruction zones.

Some of the urban spatial strategies of Tehran's Master Plan which can affect the densification process include:

- Urban consolidation.

- Limitation of the residential expansion towards the outer west wards (AMRs 21 and 22) and the reorganization of the function of these wards for clean industrial activities, productive services, green spaces, tourism, and information technology.

- Matching the residential and employment spatial patterns that are expected to be in line with the natural and historical capacities of the city; avoiding fragmentation and spatial dualism (north-south).

- Improving the old center of Tehran to develop cultural and touristic functions.

- Ensuring a balanced distribution of services and reducing travel demand via the establishment of new regional centers.

The other goals and spatial strategies of the Master Plan of Tehran include decentralization from the city center, modifying the current mono-centric structure of the city, and shaping the network structure of the city by establishing a hierarchical system of centers and services at different scales. (In this section of the Master Plan, 11 main centers in Tehran are proposed with functions at the national and international scales).

A set of land uses and FAR regulations were provided for the four functional main zones, including residential, commercial/service, mixed-use, and preserved/green zones. In this plan, the FAR percentage was determined from $80 \%$ to $440 \%$ (except for the high-rise building sub-zones), in consideration of the different land uses and based on the parcel area and street width.

All land uses, based on the corresponding regulations in the four main functional zones, were determined as follows.

The residence zone, with an area of 266 square kilometers, consisted predominantly of the residential land use and included the street network and residential supportive services (e.g., schools, grocery stores, local parks, etc.). To ensure safety and peace in this macro zone, establishing a wide range of activities was forbidden or conditional, and only establishing local-scale services related to the daily needs of the residents was allowed (Table 2). 
Table 2. Floor area ratio (FAR) regulations in the residential zone of the Master Plan of Tehran 2007.

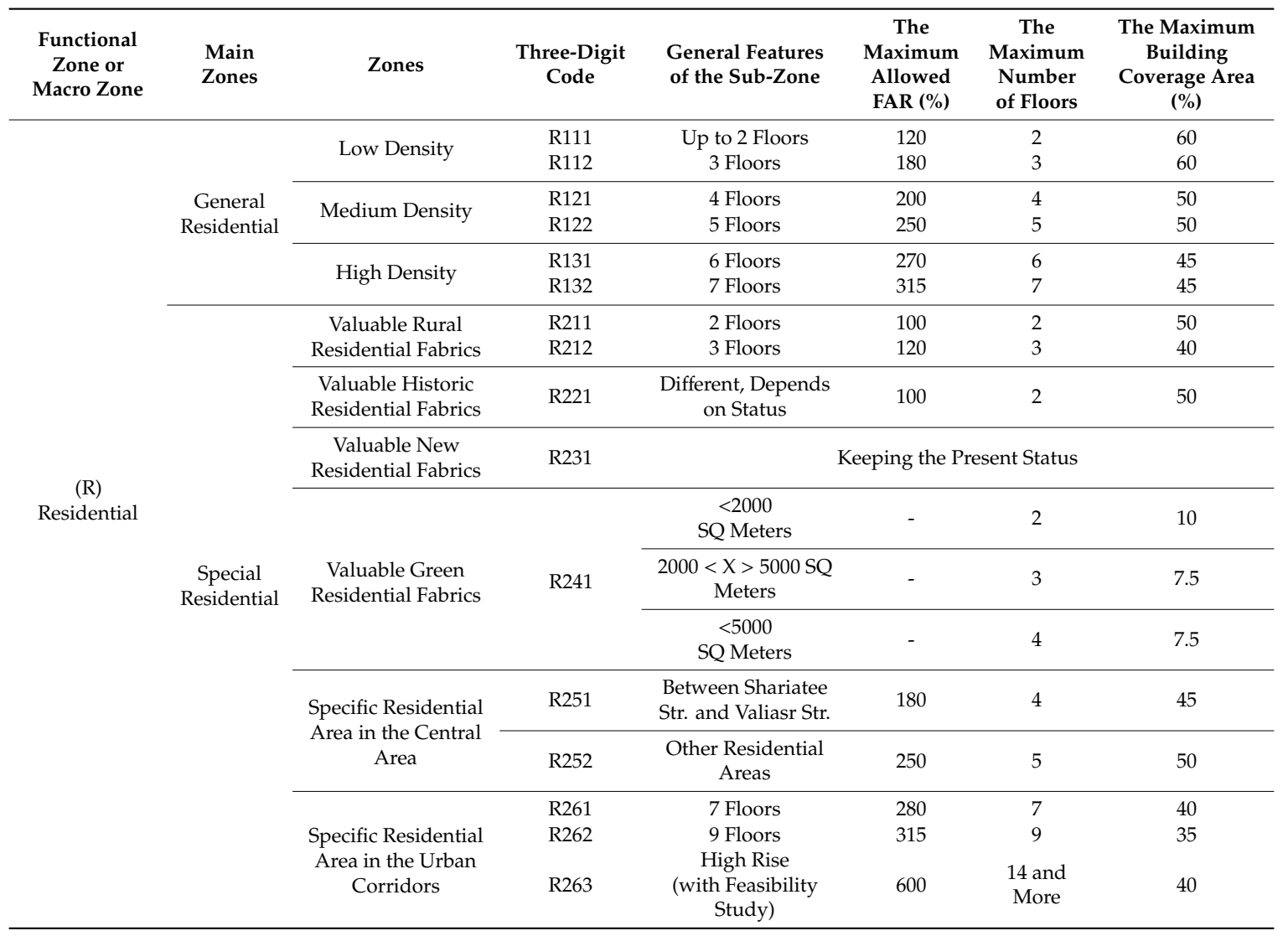

The dominant feature of the commercial and service zone, with an area of 182 square kilometers, was business and services, while the proportion of residence was very limited. Some parts of this zone were placed in the highly dense area of employment with weak access, while other parts were located in areas with high access to the main street network and main stations in the new emerging centers (Table 3).

Table 3. FAR regulations in the commercial and service zone of the Master Plan of Tehran 2007.

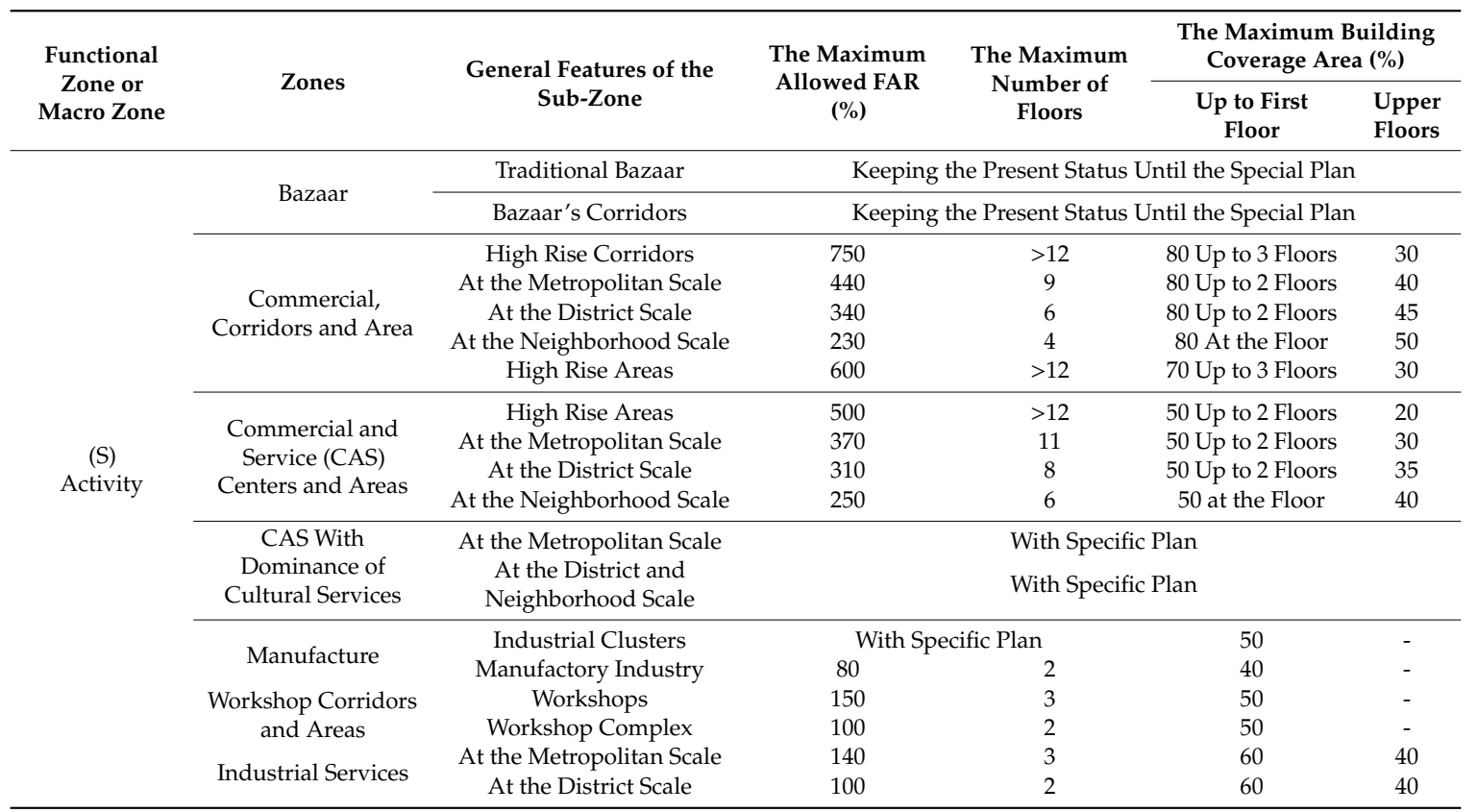


The mixed-use zone comprised an area of 47 square kilometers, which was formed either by the growth of commercial spaces in the residential context or areas with the capacity of housing multipurpose activities related to work, services, residence, or leisure (Table 4).

The green preservation zone comprised an area of 107 square kilometers of green and open public or private spaces, forest parks, orchards, farmlands, and special protected natural areas. Considering the crucial role of this zone in improving the environmental quality and the natural landscape of Tehran, building construction in this area was very limited or often forbidden. This zone was mostly allocated for the purposes of recreational and tourist activities (Table 4).

According to the modeling of a set of FAR regulations, each main functional zone exemplifies that the actual results would contradict the approved goals and strategies of the Master Plan of Tehran. As it is mentioned, the main goals and spatial strategies of the master plan emphasized the urban consolidation, limitation of the residential expansion towards the outer wards, matching the residential and employment spatial patterns, improving the old center of Tehran, etc. The modeling of FAR regulations via the Getis-Ord Local G Statistic indicates that the spatial pattern of population in Tehran would become dispersed if the Master Plan is realized. This goes against the plan's strategies and also against the status quo, which has shaped a polycentric pattern from 1996 to 2011 (Figures 2 and 3 and Table 5).

Moreover, employing the geographic weighted regression (GWR) model indicates that the population spatial pattern that is modeled based on the planned density regulations (2007) has no significant spatial correlation with the population pattern of Tehran in 2006 (Table 6 and Figure 4).

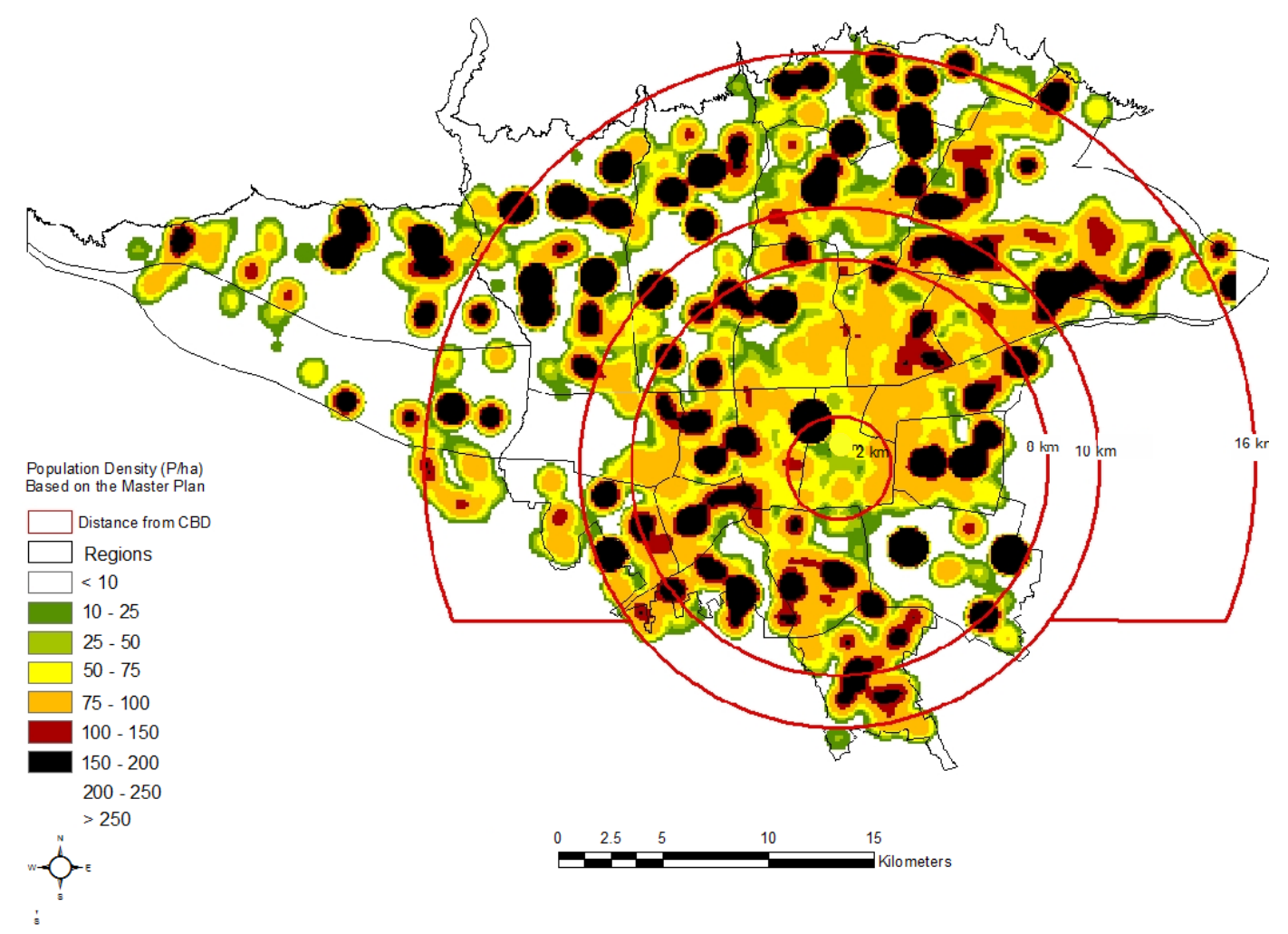

Figure 3. The spatial pattern of the population of Tehran based on the density regulations of the Master Plan *. (Data source: the FAR regulations of the Master Plan). * The ring around the old city center of Tehran is just to show the scale of the city and serves no analytical purpose in the paper. 
Table 4. FAR regulations in the mixed-use and the preservation zones of the Master Plan of Tehran 2007.

\begin{tabular}{|c|c|c|c|c|c|c|c|}
\hline $\begin{array}{l}\text { Functional Zone or } \\
\text { Macro Zone }\end{array}$ & Zones & General Features of the Sub-Zone & $\begin{array}{l}\text { The Maximum } \\
\text { Allowed FAR (\%) }\end{array}$ & $\begin{array}{l}\text { The Maximum } \\
\text { Number of Floors }\end{array}$ & $\begin{array}{r}\text { The Maximum Bui } \\
\text { Up to First Floor }\end{array}$ & $\begin{array}{l}\text { Ooverage Area (\%) } \\
\text { Upper Floors }\end{array}$ & $\begin{array}{l}\text { Minimum Potential Residential } \\
\text { Development Proportion }\end{array}$ \\
\hline \multirow{9}{*}{$\begin{array}{c}\text { (M) } \\
\text { Mixed-Use }\end{array}$} & \multirow{4}{*}{$\begin{array}{c}\text { Mixed-Use (Commercial, } \\
\text { Administrative, Service and } \\
\text { Residential }\end{array}$} & $\begin{array}{l}\text { Intra-District Mixed-Use and High-Rise } \\
\text { Corridors }\end{array}$ & 440 & 9 & 80 & 40 & 40 \\
\hline & & District Mixed-Use Corridors & 350 & 7 & 80 & 45 & 50 \\
\hline & & Neighborhood Mixed-Use Corridors & 280 & 5 & 80 & 50 & 60 \\
\hline & & Mixed-Use Areas & 200 & 4 & 50 & 50 & 50 \\
\hline & \multirow{2}{*}{$\begin{array}{c}\text { Industrial Services, } \\
\text { Workshops and Residential } \\
\end{array}$} & Mixed-Use Corridors & 250 & 5 & 50 & 50 & 20 \\
\hline & & Mixed-Use Areas & 150 & 3 & 50 & 50 & 25 \\
\hline & \multirow{2}{*}{ Recreational and Cultural } & \multirow{2}{*}{$\begin{array}{l}\text { Dominance of Cultural and Art Services } \\
\text { Dominance of Tourism and Recreational } \\
\text { Services }\end{array}$} & 150 & 3 & 50 & 50 & 30 \\
\hline & & & 200 & 2 & 60 & 60 & 35 \\
\hline & Special Mixed-Use & $\begin{array}{l}\text { Dominance of Pilgrimage } \\
\text { Historic Fabrics }\end{array}$ & \multicolumn{4}{|c|}{$\begin{array}{l}\text { Keeping the Present Status Until the Special Plan } \\
\text { Keeping the Present Status Until the Special Plan }\end{array}$} & $\begin{array}{l}40 \\
40\end{array}$ \\
\hline
\end{tabular}


Table 5. The impact of Tehran's Master Plan (2007) on the spatial pattern of population and employment in Tehran.

\begin{tabular}{|c|c|c|}
\hline Variable & Gi Results & Resulted Spatial Structure \\
\hline Population 1996 & $\begin{array}{c}\mathrm{Gi}=0.0000 \\
\mathrm{Z} \text { score }=3.03\end{array}$ & High Clusters, Polycentric \\
\hline Population 2011 & $\begin{array}{l}\mathrm{Gi}=0.000475 \\
\mathrm{Z} \text { score }=5.30\end{array}$ & High Clusters, Polycentric \\
\hline \multicolumn{3}{|c|}{ Master Plan of Tehran } \\
\hline Population (based on the Master Plan) & $\begin{array}{c}\text { Z score }=-1.429 \\
p \text { Value }=0.152\end{array}$ & Dispersed \\
\hline Activities (based on the Master Plan) & $\begin{array}{c}\text { Z score }=-0.344 \\
p \text { Value }=0.730\end{array}$ & Dispersed \\
\hline
\end{tabular}

Table 6. Spatial relation of the current pattern of population/employment and the resulting pattern of the Master Plan of Tehran (2007).

\begin{tabular}{ccc}
\hline Spatial Relation Between: & Type of Test & Result \\
\hline $\begin{array}{c}\text { The Current Spatial Pattern of Population (2006) and } \\
\text { the Resulted Spatial Pattern of Population of the } \\
\text { Master Plan 2007 }\end{array}$ & $\begin{array}{c}\text { GWR R }=0.031 \\
\text { GWR R } \text { R }^{2}=0.03\end{array}$ & No Spatial Relationship \\
\hline $\begin{array}{c}\text { Resulted Spatial Population and Activity of the } \\
\text { Master Plan }\end{array}$ & $\begin{array}{c}\text { GWR R }=0.07 \\
\text { GWR R }=0.05\end{array}$ & No Spatial Relationship \\
\hline $\begin{array}{c}\text { The Current Spatial Pattern of Population and } \\
\text { Activity of Tehran in 2006 }\end{array}$ & $\begin{array}{c}\text { GWR R }=0.75 \\
\text { GWR R }=0.72\end{array}$ & High Spatial Relationship \\
\hline
\end{tabular}
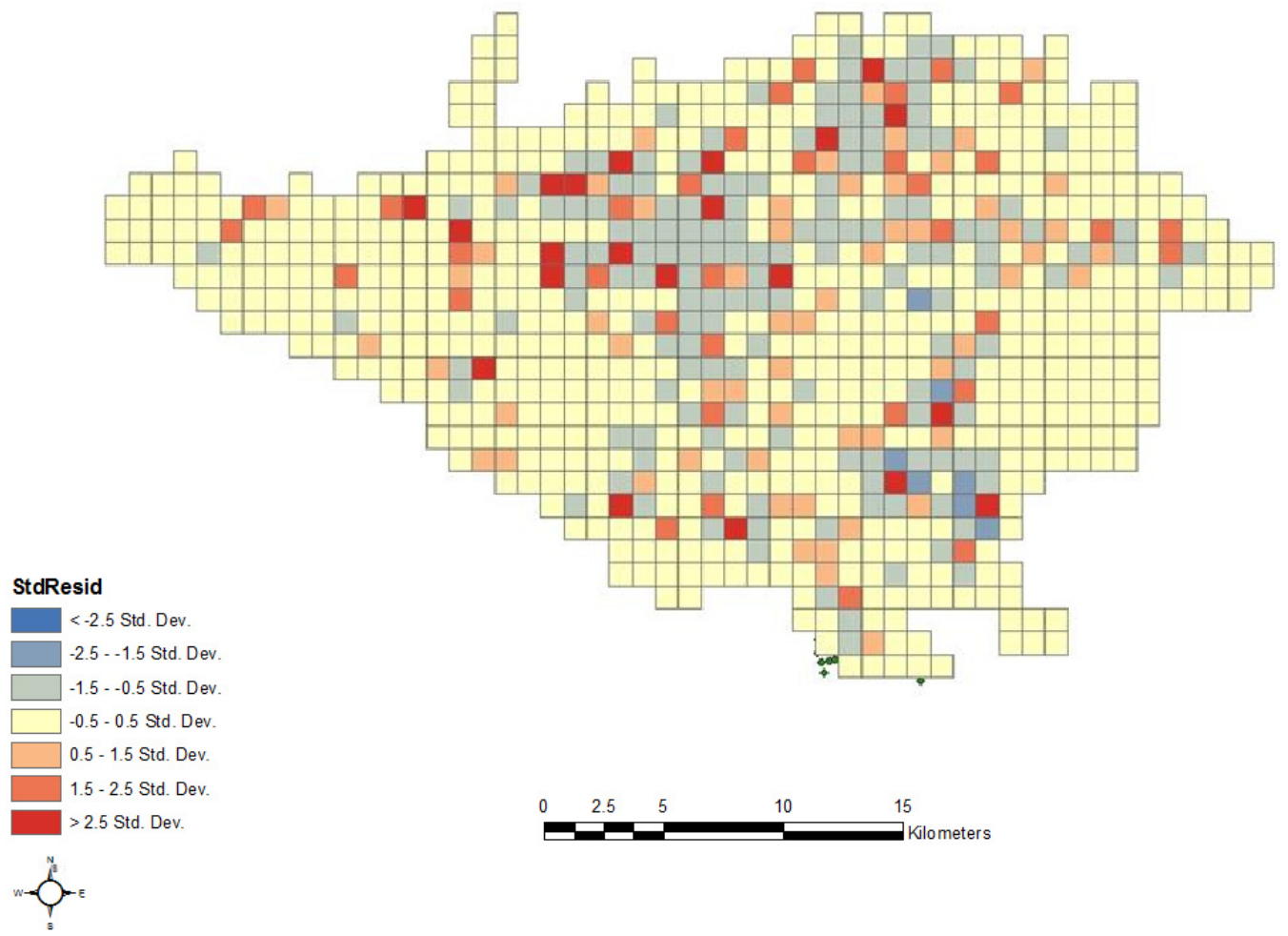

Figure 4. The lack of spatial correlation in the proposed pattern of population distribution in the Master Plan (2007) and the population distribution pattern in Tehran in 2006. (Data source: the FAR regulations of the Master Plan). 
In fact, the current polycentric population pattern of this metropolis has been ignored in the plan and is being transformed into a dispersed structure. This indicates ignorance of the past structuring pattern and status quo in the formulation of the spatial strategy (Table 6).

The density policies of the plan would facilitate more population growth towards the outer areas of Tehran. By decreasing the population concentration from the central and the inner areas, the proposed plan would result in the population growth in the outer areas, especially in the outer north wards. The demographic profile gradient, in line with the social and economic base gradients, would be from the north to the south, in that $77.3 \%$ of the population will settle in the outer areas, $14.8 \%$ in the inner areas, and $7.8 \%$ in the central area. Interestingly, the density policies of the plan are in line with the construction investment pattern and the desire of developers who are seeking more profits through construction in the outer north and outer west areas of Tehran (Figures 5 and 6).

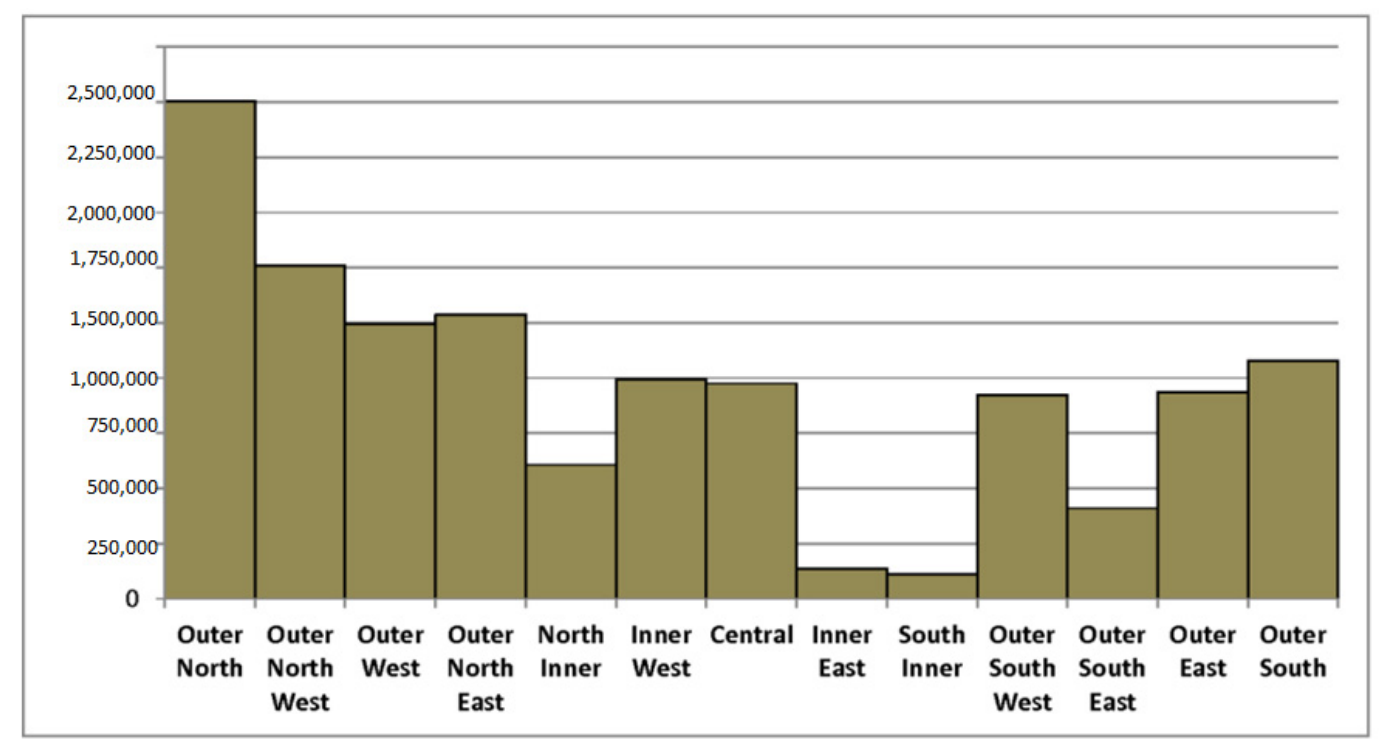

Figure 5. The population of the main wards from the north to the south of Tehran as a result of the FAR policies of the Master Plan in 2007. (Data source: the FAR regulations of the Master Plan).

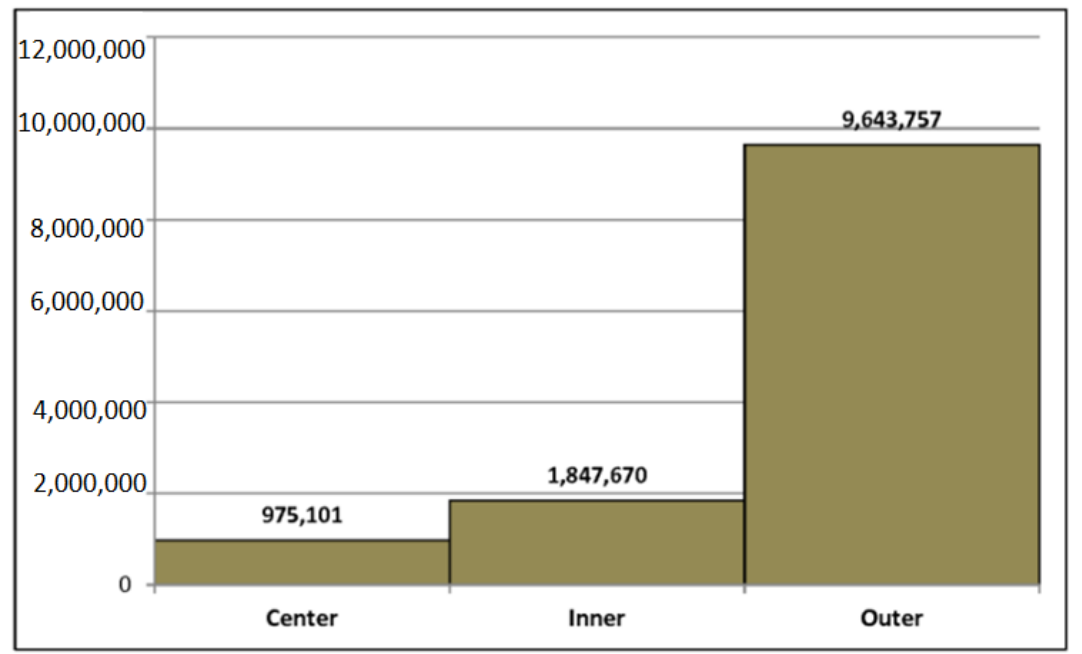

Figure 6. The population of the main areas of Tehran as a result of the FAR policies of the Master Plan in 2007. (Data source: the FAR regulations of the Master Plan).

Although it is expected that the spatial pattern of employment would be well organized after the approval and implementation of the Master Plan, the modeling of the density regulations via 
the Getis-Ord Local G Statistic indicates that the Master Plan of Tehran would change the current polycentric pattern of employment into a dispersed one that lacks the main business hubs. This result would undermine the function of current employment hubs and lead to the establishment of several weak employment centers throughout the city (Figure 7 and Table 6).

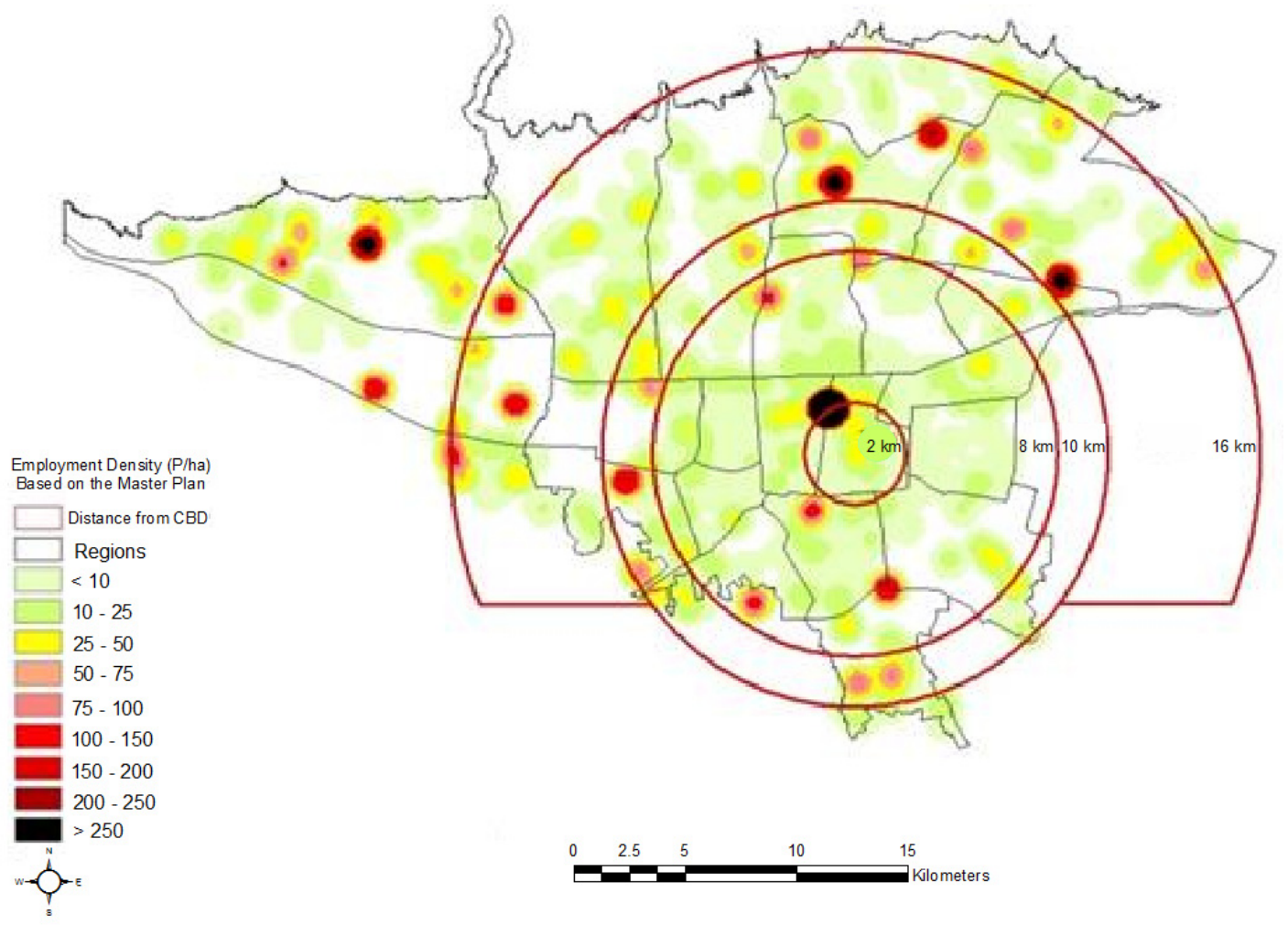

Figure 7. Spatial pattern of employment density of Tehran as a result of the FAR policies of the Master Plan in 2007 (Employment/ha) *. (Data source: the FAR regulations of the Master Plan). * The ring around the old city center of Tehran is just to show the scale of the city and serves no analytical purpose in the paper.

The relationship between the population and the employment spatial patterns is the other measure that can indicate the quality of the densification policies and strategies. The modeling of density regulations via the GWR model indicates a non-significant spatial correlation $\left(R^{2}=0.05\right)$ between the resulting spatial patterns of population and employment (Figure 8), whereas the degree of spatial correlation between the status quo spatial patterns of employment and population in Tehran (2006) is much stronger $\left(R^{2}=0.72\right)$. In fact, the results also suggest that the resulting spatial pattern of population in the Master Plan neither matches the current population pattern nor considers the spatial relationship of the population and employment in its density strategies and policies. This would lead to the unbalancing of the spatial structure of this metropolis (Table 6). The spatial separation of the density nuclei of population from the density nuclei of commercial activities translates into an increase in the distance between work and residence clusters, which in turn would increase the need for longer and more frequent travel and entails a variety of negative economic, social, and environmental consequences. 


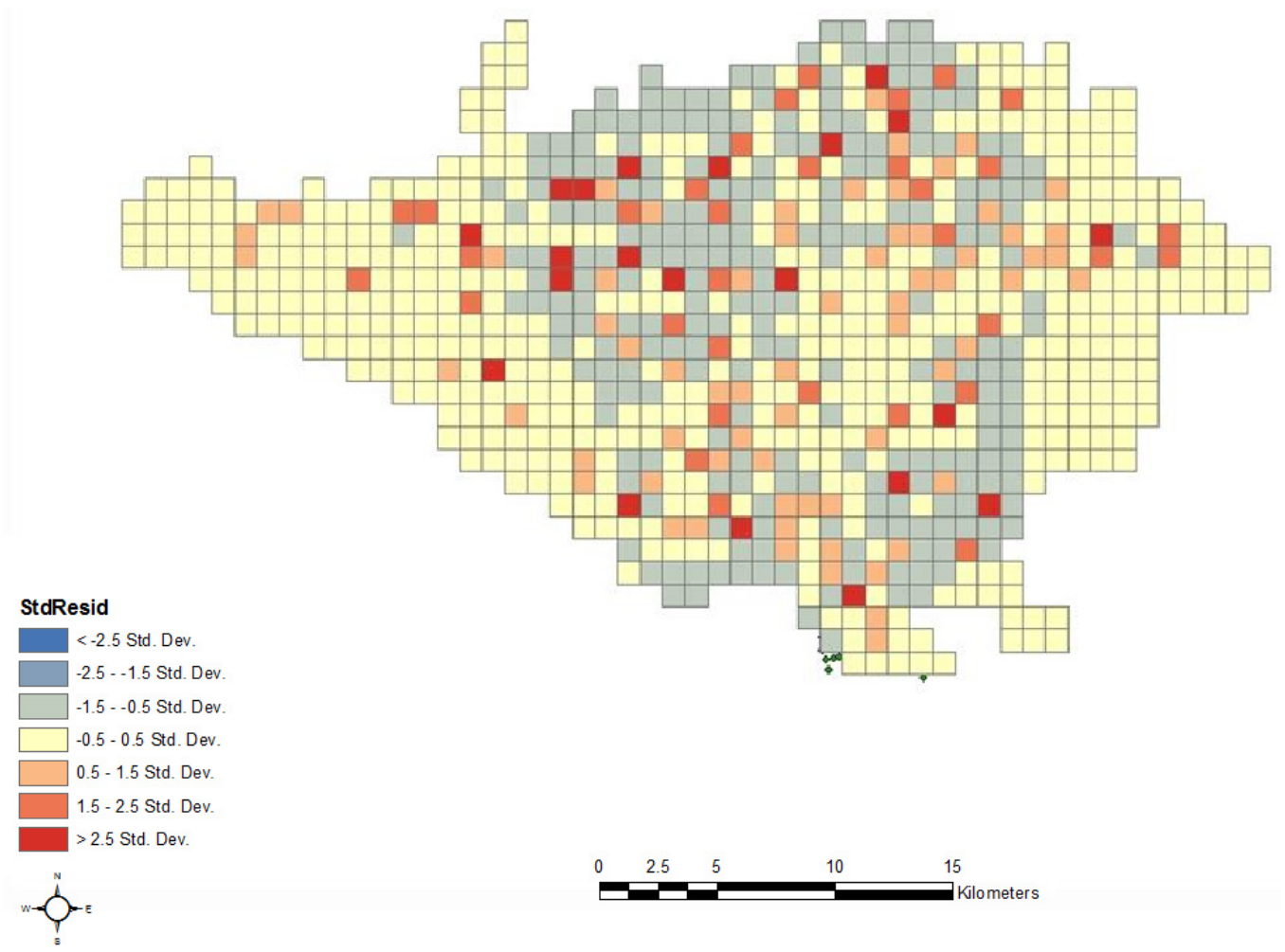

Figure 8. The lack of spatial correlation in the resulting pattern of population and employment in the Master Plan of Tehran in 2007. (Data source: the FAR regulations of the Master Plan).

\section{Conclusions}

The aim of this study was to uncover the importance of urban spatial structure as the macro scale in density policy-making and research. Density is one of the most frequently employed measures in the literature of urban sustainable development; meanwhile, its effectiveness for achieving the claimed positive goals is questionable.

The analytical results indicated that the densification policies of Tehran have key weaknesses in two dimensions. First, there was a serious incompatibility between the density policies and the goals of the Master Plan. In fact, the goals of the plan emphasize an integrated and balanced urban structure for residence, work, and leisure; reducing inequalities; sustainable urban development; improving the quality of the environment; and sustainable transportation. However, the results of this study indicated that the spatial pattern of population and employment in Tehran would have a dispersed structure if the density policies of the Master Plan were implemented. These results are in contrast with the goals and strategies of the plan. Furthermore, there was no significant spatial relationship between the spatial pattern of population and employment resulting from the FAR policies of the plan. On the contrary, implementing the FAR regulations would result in meaningful distance between the population and the employment clusters. This is evidence of another case of disparity between the goals and policies of the plan.

Second, the densification policies in the Master Plan of Tehran did not match with the current pattern of the city's spatial structure, suggesting ignorance of the ongoing trends and the present pattern that has been shaped for decades. The results indicated that the density policies of the plan would lead to a non-spatial integration and dispersed structure, while the current population and employment structure of Tehran is polycentric.

The main finding of this research implies that urban spatial structure has a significant influence on density policy effectiveness. Indeed, here, the important point in densification planning is to consider the current spatial structure in which the densification process is occurring and to predict what type of spatial structure will emerge when the planned densification is implemented. This research showed 
the weakness of both the gross average density approach as well as the neighborhood scale approach of density policy. The results showed that both the approaches failed to capture the macro structure of the city, which is configured by spatial patterns of population, employment, services, and networks.

The average density of Tehran as the case study was $128 \mathrm{P} /$ ha in 2011 , which is categorized as a high-density value. However, this city never enjoyed any of the claimed positive effects of high density. Heavy traffic, high VMT, and air pollution turned into a crisis for Tehran's inhabitants [79-81]. As Neuman (2005) and Handy (1992) argue, average density tends to reduce the complex entity of urban form differentiations into one crude criterion. Several other authors are critical of this approach, as well [45,80-82].

Analyzing the density policy of the Master Plan of Tehran also revealed that referring to density at the micro scale (such as a block or a neighborhood) is also too small to capture the whole structural picture of the city. This result is in line with the handful of studies that examined the effects of density at the neighborhood and urban structure scales on commuting, VMT, and the green hose gas (GHG). In fact, the results of all these studies imply that the urban spatial structure as the macro spatial scale can overwhelm neighborhood-scale effects $[11,32,51,59,82]$. In a study on the impacts of density at the neighborhood and city scales in China and the USA, Sun and Yin (2019) and Lee (2015) showed that commuters' workplaces are usually far beyond neighborhood areas, requiring a long commute from their neighborhood boundaries. The aforementioned studies also observed the failure of focusing on neighborhood units in the study of the effects of density on inhabitants' behaviors.

The contribution of this research is two-fold. First, this research followed a different approach, which was missing in the related studies on densification. Without considering the macro spatial configuration of the hot and cold spots of population and employment, average density measurements at the city or neighborhood scales will miss crucial information about the distribution pattern of spatial factors. Second, this study provided a case of density policies in practice in the context of a developing country. During the research, all of the relevant regulation texts were translated into a geographical understanding by using maps and geo-statistics.

The study conducted modeling of the spatial outcomes of implementing the density policies of Tehran's Master Plan in a time-consuming process for the first time. The plan is trusted by the municipality and is supposed to direct the spatial changes in the city for the next 10 years. However, the current study faced some limitations regarding access to the updated information of the case study, which took some months to conduct. Future studies can investigate the economic, social, and environmental consequences of the density policies of Tehran. It should also be added that the spatial structure of Tehran is mostly the product of the long-time implementation of unplanned densification policies (before the Master Plan) and a plan which lacks the spatial approach to densification policies (after the Master Plan). Finally, this study sought to emphasize the importance of macro spatial dimensions in urban densification policies.

Author Contributions: Conceptualization and the theory, A.D.; Methodology, M.G. and T.S.; Formal Analysis, M.G. and T.S.; Resources, A.D.; Writing-Review \& Editing, M.G. and T.S.; Supervision, A.D.; Funding Acquisition, A.D. All authors have read and agreed to the published version of the manuscript.

Funding: This research was funded by the Alexander von Humboldt Foundation as a fellowship program, grant number 107201930062021.

Conflicts of Interest: The authors declare no conflict of interest.

\section{References}

1. Bertaud, A. The Spatial Organization of Cities: Deliberate Outcome or Unforeseen Consequence? Available online: https://escholarship.org/uc/item/5vb4w9wb (accessed on 1 July 2004).

2. Bertaud, A.; Malpezzi, S. The spatial distribution of population in 48 world cities: Implications for economies in transition. Cent. Urban Land Econ. Res. 2003, 32, 54-55. 
3. Boarnet, M.G.; Crane, R. Travel by Design: The Influence of Urban form on Travel, 1st ed.; Oxford University Press: New York, NY, USA, 2001; Available online: https://www.questia.com/library/104890670/travel-bydesign-the-influence-of-urban-form-on (accessed on 10 September 2019).

4. Ding, C.R.; Zhao, X.S. Land market, land development and urban spatial structure in Beijing. Land Use Policy 2014, 40, 83-90. [CrossRef]

5. Grosvenor, M.; O'Neill, P. The density debate in urban research: An alternative approach to representing urban structure and form. Geogr. Res. 2014, 52, 442-458. [CrossRef]

6. Marshall, J.D. Reducing urban sprawl could play an important role in addressing climate change. Environ. Sci. Technol. 2008, 42, 3133-3137. Available online: http://pascal-francis.inist.fr/vibad/index.php?action= getRecordDetail\&idt=20310174 (accessed on 10 September 2019). [CrossRef]

7. Pili, S.; Grigoriadis, E.; Carlucci, M.; Clemente, M.; Salvati, L. Towards sustainable growth? A multi-criteria assessment of (changing) urban forms. Ecol. Indic. 2017, 76, 71-80. [CrossRef]

8. Simpson, W. Workplace Location, Residential Location, and Urban Commuting. Urban Stud. 1987, 24, 119-128. [CrossRef]

9. Soltani, A.; Hosseinpour, M.; Hajizadeh, A. Urban sprawl in Iranian medium-sized cities; investigating the Role of Master plans. J. Sustain. Dev. 2017, 10, 122-131. [CrossRef]

10. Lin, D.; Allan, A.; Cui, J. The impacts of urban spatial structure and socio-economic factors on patterns of commuting: A review. Int. J. Urban Sci. 2015, 19, 238-255. [CrossRef]

11. Zhang, T.L.; Sun, B.D.; Li, W. The economic performance of urban structure: From the perspective of Polycentricity and Monocentricity. Cities 2017, 68, 18-24. [CrossRef]

12. Azami, M.; Mirzaee, E.; Mohammadi, A. Recognition of urban unsustainability in Iran (case study: Sanandaj City). Cities 2015, 49, 159-168. [CrossRef]

13. Jenks, M. Conclusion: The appropriateness of compact city concepts to developing countries. In Compact Cities: Sustainable Urban forms for Developing Countries, 1st ed.; Burgess, R., Jenks, M., Eds.; Routledge: London, UK, 2000; pp. 343-350.

14. Dave, S. High urban densities in developing countries: A sustainable solution? Built Environ. 2010, 36, 9-27. [CrossRef]

15. Mashayekhi, A. The 1968 Tehran master plan and the politics of planning development in Iran (1945-1979). Plan. Perspect. 2019, 34, 849-876. [CrossRef]

16. Masoumi, H.E.; Hosseini, M.; Gouda, A.A. Drivers of urban sprawl in two large Middle-eastern countries: Literature on Iran and Egypt. Hum. Geogr. 2018, 12, 55-79. [CrossRef]

17. Pahlavani, P.; Sheikhian, H.; Bigdeli, B. Evaluation of residential land use compatibilities using a density-based IOWA operator and an ANFIS-based model: A case study of Tehran, Iran. Land Use Policy 2020, 90, 104364. [CrossRef]

18. Richardson, H.W.; Bae, C.-H.C.; Baxamusa, M.H. Compact cities in developing countries: Assessment and implications. In Compact Cities: Sustainable Urban forms for Developing Countries, 1st ed.; Burgess, R., Jenks, M., Eds.; Routledge: London, UK, 2000; pp. 25-36.

19. Shifaw, E.; Sha, J.M.; Li, X.M.; Shang, J.L.; Bao, Z.C. Remote sensing and GIS-based analysis of urban dynamics and modelling of its drivers, the case of Pingtan, China. Environ. Dev. Sustain. 2020, 22, 2159-2186. [CrossRef]

20. Ghadami, M.; Newman, P. Spatial consequences of urban densification policy: Floor-to-area ratio policy in Tehran, Iran. Environ. Plan. B Urban Anal. City Sci. 2019, 46, 626-647. [CrossRef]

21. Ewing, R.; Hamidi, S. Compactness versus sprawl: A review of recent evidence from the United States. J. Plan. Lit. 2015, 30, 413-432. [CrossRef]

22. Krehl, A.; Siedentop, S.; Taubenböck, H.; Wurm, M. A Comprehensive View on Urban Spatial Structure: Urban Density Patterns of German City Regions. ISPRS Int. J. Geo-Inf. 2016, 5, 76. [CrossRef]

23. Berg, P.; Granvik, M.; Hedfors, P. Functional density: A conceptual framework in a townscape areas context. Nord. J. Arch. Res. 2012, 2, 29-46.

24. Bardhan, R.; Kurisu, K.; Hanaki, K. Does compact urban forms relate to good quality of life in high density cities of India? Case of Kolkata. Cities 2015, 48, 55-65. [CrossRef]

25. Jenks, M.; Jones, C. (Eds.) Dimensions of the Sustainable City; Springer: Dordrecht, The Netherlands, 2010; Volume 2 . 
26. Milder, J. Sustainable urban form. In Sustainable Urban Environments: An Ecosystem Approach; van Bueren, E., van Bohemen, H., Itard, L.C.M., Visscher, H., Eds.; Springer: Dordrecht, The Netherlands, 2012; pp. 263-284.

27. Ferguson, N.; Woods, L. Travel and mobility. In Dimensions of the Sustainable City; Jenks, M., Jones, C., Eds.; Springer: Dordrecht, The Netherlands, 2010; pp. 53-74.

28. Schmidt-Thomé, K.; Haybatollahi, M.; Kyttä, M.; Korpi, J. The prospects for urban densification: A place-based study. Environ. Res. Lett. 2013, 8, 025020. [CrossRef]

29. Beck, A.; Stave, K. Understanding urban quality of life and sustainability. In Proceedings of the 29th International Conference of the System Dynamics Society, Washington, DC, USA, 24-28 July 2011.

30. Dempsey, N.; Jenks, M. The future of the compact city. Built Environ. 2010, 36, 116-121. [CrossRef]

31. Williams, K. Can Urban Intensification Contribute to Sustainable Cities? An International Perspective. City Matters, 2004. Available online: https://pdfs.semanticscholar.org/6da8/a1c80cffef60e645053d3f9cc122303bf06d. pdf (accessed on 15 September 2019).

32. Lee, S. The Role of Urban Spatial Structure in Reducing VMT and GHG Emissions. Ph.D. Thesis, University of Illinois at Urbana-Champaign, Illinois, IL, USA, 2015.

33. Eager, W.R. Accommodating land use and transportation planning. In Land Use in Transition; The Urban Land Institute: Washington, DC, USA, 1993; pp. 32-37.

34. Gomez-Ibanez, J.A. Big-city transit rider snip, deficits, and politics: Avoiding reality in Boston. J. Am. Plann. Assoc. 1991, 61, 30-50. [CrossRef]

35. Schwarz, N. Urban form revisited-Selecting indicators for characterising European cities. Landsc. Urban Plan. 2010, 96, 29-47. [CrossRef]

36. Amindarbari, R.; Sevtsuk, A. Measuring Growth and Change in Metropolitan form. Progress Report on Urban form and Land use Measures: Measuring Growth and Change in East-Asian Cities; Singapore: 2012. Available online: http://media.voog.com/0000/0036/2451/files/Measuring_Growth_and_Change_in_ Metropolitan_Form.pdf (accessed on 15 September 2019).

37. Neuman, M. The compact city fallacy. J. Plan. Educ. Res. 2005, 25, 11-26. [CrossRef]

38. Bamford, G. Urban form and housing density, Australian cities and European models: Copenhagen and Stockholm reconsidered. Urban Pol. Res. 2009, 27, 337-356. [CrossRef]

39. Muñiz, I.; Galindo, A. Urban form and the ecological footprint of commuting. The case of Barcelona. Ecol. Econ. 2005, 55, 499-514. [CrossRef]

40. Burton, E.J. Measuring urban compactness in UK towns and cities. Environ. Plan. B Plan. Des. 2002, 29, 219-250. [CrossRef]

41. Jenks, M.; Burton, E.; Williams, K. Measuring and monitoring: Introduction. In The Compact City: A Sustainable Urban form? 1st ed.; Burton, E., Jenks, M., Williams, K., Eds.; Taylor \& Francis: London, UK, 1996; pp. $215-216$.

42. Newman, P.; Kenworthy, J. (Eds.) Sustainability and Cities: Overcoming Automobile Dependence; Island Press: Washington, DC, USA, 1999.

43. OECD. The compact city concept in today's urban contexts. In Compact City Policies: A Comparative Assessment; OECD Publishing: Paris, France, 2012; Available online: https://read.oecd-ilibrary.org/urban-ruraland-regional-development/compact-city-policies/the-compact-city-concept-in-today-s-urban-contexts_ 9789264167865-6-en\#page4 (accessed on 1 September 2019).

44. Newman, P. The environmental impact of cities. Environ. Urban. 2006, 18, 275-295. [CrossRef]

45. Holden, E.; Norland, I.T. Three challenges for the compact city as a sustainable urban form: Household consumption of energy and transport in eight residential areas in the Greater Oslo Region. Urban Stud. 2005, 42, 2145-2166. [CrossRef]

46. Næss, P. Urban form and travel behavior: Experience from a Nordic context. J. Transp. Land Use 2012, 5, 21-45. [CrossRef]

47. Bramley, G.; Power, S. Urban form and social sustainability: The role of density and housing type. Environ. Plan. B Plan. Des. 2009, 36, 30-48. [CrossRef]

48. Kyttä, M.; Broberg, A.; Tzoulas, T.; Snabb, K. Towards contextually sensitive urban densification: Location-based softGIS knowledge revealing perceived residential environmental quality. Landscape Urban Plan. 2013, 113, 30-46. [CrossRef]

49. Residential Density Guide; Landcom: Sydney, Australia, 2011; Available online: https://www.landcom.com. au/assets/Publications/Statement-of-Corporate-Intent/8477325cc1/Density-Guide-Book.pdf (accessed on 1 September 2019). 
50. Newman, P.W.G.; Kenworthy, J.R. Gasoline consumption and cities: A comparison of US cities with a global survey. J. Am. Plann. Assoc. 1989, 55, 24-37. [CrossRef]

51. Pucher, J. Urban travel behavior as the outcome of public policy: The example of modal-split in Western Europe and North America. J. Am. Plann. Assoc. 1988, 54, 509-520. [CrossRef]

52. McFarlane, C. The geographies of urban density: Topology, politics and the city. Prog. Hum. Geogr. 2016, 40, 629-648. [CrossRef]

53. Huang, X.Y.; Yang, J.W.; Güneralp, B.; Burris, M. US Metropolitan Spatial Structure Evolution: Investigating Spatial Patterns of Employment Growth from 2000 to 2010. Urban Sci. 2017, 1, 28. [CrossRef]

54. Cao, J.; Mokhtarian, P.L.; Handy, S.L. Neighborhood design and vehicle type choice: Vidence from Northern California. Transp. Res. D Transp. Environ. 2006, 11, 133-145. [CrossRef]

55. Cervero, R.; Kockelman, K. Travel demand and the 3Ds: Density, diversity, and design. Transp. Res. D Transp. Environ. 1997, 2, 199-219. [CrossRef]

56. Barr, J.; Cohen, J.P. The floor area ratio gradient: New York City, 1890-2009. Reg. Sci. Urban Econ. 2014, 48, 110-119. [CrossRef]

57. Bento, A.M.; Cropper, M.L.; Mobarak, A.M.; Vinha, K. The effects of urban spatial structure on travel demand in the United States. Rev. Econ. Stat. 2005, 87, 466-478. [CrossRef]

58. Cervero, R.B.; Murakami, J. Effects of built environments on vehicle miles traveled: Evidence from 370 US urbanized areas. Environ. Plan A 2010, 42, 400-418. [CrossRef]

59. Rodríguez, M.C.; Dupont-Courtade, L.; Oueslati, W. Air pollution and urban structure linkages: Evidence from European cities. Renew. Sust. Energ. Rev. 2016, 53, 1-9. [CrossRef]

60. Aquino, F.L.; Gainza, X. Understanding Density in an Uneven City, Santiago de Chile: Implications for Social and Environmental Sustainability. Sustainability 2014, 6, 5876-5897. [CrossRef]

61. Boyko, C.T.; Cooper, R. Clarifying and re-conceptualising density. Prog. Plann. 2011, 76, 1-61. [CrossRef]

62. Sivam, A.; Karuppannan, S.; Davis, M.C. Stakeholders' perception of residential density: A case study of Adelaide, Australia. J. Hous. Built Environ. 2012, 27, 473-494. [CrossRef]

63. Alexander, D.; Tomalty, R. Smart Growth and Sustainable Development: Challenges, solutions and policy directions. Local Environ. 2002, 7, 397-409. [CrossRef]

64. Kytta, M.; Kahila, M.; Broberg, A.K. Perceived environmental quality as an input to urban infill policy-making. Urban Des. Int. 2011, 16, 19-35. [CrossRef]

65. Getis, A.; Ord, J.K. The analysis of spatial association by use of distance statistics. Geogr. Anal. 1992, 24, 189-206. [CrossRef]

66. Griffith, A.D.; Wong, W.D. Modeling population density across major US cities: A polycentric spatial regression approach. J. Geogr. Syst. 2007, 9, 53-75. [CrossRef]

67. Charlton, M.; Fotheringham, S.; Brunsdon, C. Geographically Weighted Regression, 2009. Available online: http://eprints.ncrm.ac.uk/90/1/MethodsReviewPaperNCRM-006.pdf (accessed on 15 August 2019).

68. Arsanjani, J.J.; Helbich, M.; de Noronha Vaz, E. Spatiotemporal simulation of urban growth patterns using agent-based modeling: The case of Tehran. Cities 2013, 32, 33-42. [CrossRef]

69. Statistical Centre of Iran. Population and Housing Censuses. Census Blocks of the City of Tehran, GIS Department, 1996. Available online: https://www.amar.org.ir/\%D8\%AF\%D8\%A7\%D8\%AF\%D9\%87\% D9\%87\%D8\%A7-\%D9\%88-\%D8\%A7\%D8\%B7\%D9\%84\%D8\%A7\%D8\%B9\%D8\%A7\%D8\%AA-\%D8\%A2\% D9\%85\%D8\%A7\%D8\%B1\%DB\%8C (accessed on 10 May 2019). (In Persian)

70. Statistical Centre of Iran. Population and Housing Censuses. Census Blocks of the City of Tehran, GIS Department, 2006. Available online: https://www.amar.org.ir/\%D8\%AF\%D8\%A7\%D8\%AF\%D9\%87\% D9\%87\%D8\%A7-\%D9\%88-\%D8\%A7\%D8\%B7\%D9\%84\%D8\%A7\%D8\%B9\%D8\%A7\%D8\%AA-\%D8\%A2\% D9\%85\%D8\%A7\%D8\%B1\%DB\%8C (accessed on 10 May 2019). (In Persian)

71. Statistical Centre of Iran. Population and Housing Censuses. Census blocks of the City of Tehran, GIS Department, 2011. Available online: https://www.amar.org.ir/\%D8\%AF\%D8\%A7\%D8\%AF\%D9\%87\% D9\%87\%D8\%A7-\%D9\%88-\%D8\%A7\%D8\%B7\%D9\%84\%D8\%A7\%D8\%B9\%D8\%A7\%D8\%AA-\%D8\%A2\% D9\%85\%D8\%A7\%D8\%B1\%DB\%8C (accessed on 10 May 2019). (In Persian)

72. Atash, F. The deterioration of urban environments in developing countries: Mitigating the air pollution crisis in Tehran, Iran. Cities 2007, 24, 399-409. [CrossRef]

73. Madanipour, A. City profile: Tehran. Cities 1999, 16, 57-65. [CrossRef] 
74. Charbgoo, N.; Mareggi, M. A framework for time studies in urban planning: Assessment of comprehensive planning in the case of Tehran. Environ. Plan. B Urban Anal. City Sci. 2018, 47, 1098-1114. [CrossRef]

75. Farhoodi, R.; Gharakhlou-N, M.; Ghadami, M.; Khah, M.P. A critique of the prevailing comprehensive urban planning paradigm in Iran: The need for strategic planning. Plan. Theory 2009, 8, 335-361. [CrossRef]

76. Madanipour, A. Urban planning and development in Tehran. Cities 2006, 23, 433-438. [CrossRef]

77. Sarkheyli, E.; Sharifi, A.; Rafieian, M.; reza Bemanian, M.; Murayama, A. An investigation of the reasons for non-compliance with FAR regulations in Tehran. Cities 2012, 29, 223-233. [CrossRef]

78. High Council of Urban Planning and Architecture of Iran. Master Plan of Tehran, Municipality of Tehran. Iran, 2007. Available online: https://www.mrud.ir/Search-Results?search=\%D8\%B7\%D8\%B1\%D8\%AD \% 20\%D8\%AC\%D8\%A7\%D9\%85\%D8\%B9\%20\%D8\%AA\%D9\%87\%D8\%B1\%D8\%A7\%D9\%86 (accessed on 15 July 2019). (In Persian)

79. Handy, S. Methodologies for exploring the link between urban form and travel behavior. Transp. Res. D Transp. Environ. 1996, 1, 151-165. [CrossRef]

80. McLoughlin, J.B. Urban consolidation and urban sprawl: A question of density? Urban Pol. Res. 1991, 9, 148-156. [CrossRef]

81. Forster, $\mathrm{C}$. The challenge of change: Australian cities and urban planning in the new millennium. Geogr. Res. 2006, 44, 173-182. [CrossRef]

82. Sun, B.D.; Yin, C. Impacts of a multi-scale built environment and its corresponding moderating effects on commute duration in China. Urban Stud. 2020, 57, 2115-2130. [CrossRef]

(C) 2020 by the authors. Licensee MDPI, Basel, Switzerland. This article is an open access article distributed under the terms and conditions of the Creative Commons Attribution (CC BY) license (http://creativecommons.org/licenses/by/4.0/). 